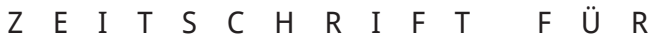

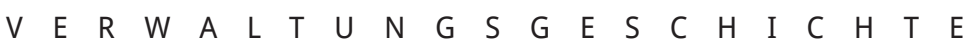

B A N D 4,20019

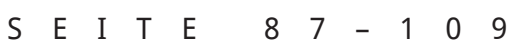

D O I : $10.2478 / \mathrm{ADH}$ I- $2019-0006$

\title{
Revisions and Revisionisms in H.O. Meisner's Modern Diplomatics of Files: An Essay in the Historical Anthropology of Bureaucratic Mediocracy
}

\author{
MARIO WIMMER ${ }^{1}$
}

$" A$ cage went in search of a bird. $\star^{2}$

In the following, I lay out an argument about the scholarship on the emergent rationality of files. I understand this essay to be a contribution to an anthropology of bureaucracy in a historical perspective. With this, I follow what Paul Rabinow has called an anthropology of reason. This rather-recent shift in cultural anthropology has established a novel mode of inquiry into the practices and institutions of Western rationality. In my critical study of how the human (anthrōpos) is reconfigured by bureaucratic thinking and practice, I take an ethical stance. Taking a close look at the practices and logics of Prussian bureaucracy in and out of the archive, I revisit the understanding of a particular province of emergent rationality. Dipesh Chakrabarty and others have made a plea for looking at the history of Europe from its (post)colonial margins. However, aside from the attempt at provincializing Europe $^{3}$, an anthropology of reason tends to exoticize Western rationalities from within. The trajectory of this research is to describe and analyze the conditions and possibilities of how reality was and still is constituted and universalized in the West, as well as how it is claimed and accepted as true due to its economic and political power. Therefore, my ambition in this essay is to take an ethnographic perspective on a marginal region within Western rationality, namely, the mundane practices and scholarly mediocracy prevalent in Prussian state archives in Weimar culture.

Under the label of Actor-Network Theory, ethnographies of bureaucracy and science ${ }^{4}$ have made use of the epistemological break ${ }^{5}$ between disciplined rationalities and everyday practices. Like the inquiry into the anthropology of reason, they succeed in questioning what seems indubitable and trace the practices that undergird the big, foundational concepts of modernity. From the perspective of praxeology, the ethnographer of science and technology, Bruno Latour, went as far as to ask whether modernity, as it was and still is imagined, ever existed in the realm of praxis. ${ }^{6}$ Viewed through this perspective, it turns out that many of the umbrella terms that organized the logics of Western rationality start to collapse. This enables one to reconsider them in 
practical, more humble, terms. The exercise of making one's indigenous culture, say Prussian bureaucracy, seem unfamiliar, peculiar, and even exotic, does require a particular perspective. This perspective is not necessarily the perspective of the stranger, the foreigner, the outsider, or that of the resident or illegal alien sans papier. In the case at point, I analyze the ethnographic encounter between Prussian bureaucracy and everyday life. The perception of a mundane scene of street life in Berlin by the well-known state archivist but hardly recognized scholar Heinrich Otto Meisner (1890-1976) will open a window to the anthropological understanding both of the emergent rationalities of bureaucracy and of the everyday. The way I situate this anecdote, Meisner turns into a reluctant ethnographer avant la lettre.

My approach is shaped by an ethics of the other that may allow us to acknowledge some of the epistemic and structural violence that undergird the ideal-typical surface of a desire for frictionless bureaucratic routine. Underneath the surface, we find a heterogeneity of distributed practices, emergent logics, and erratic desires. Since each discourse is heterologic, every practice harbors within it something that is different from how it is understood by the actors and institutions engaging with it on a daily level. ${ }^{7}$ This opens up the possibility of an ethnographic perspective, in which bureaucracy can be viewed through the lens of everyday life and vice versa; furthermore, the excessive materiality of intellectual processes provides the resources for a historical anthropology of reason. This holds true, as I will show, for bureaucracy as much as for everyday life. In the case of bureaucratic administration, particularly in relation to archival filing systems, state institutions set out to catch Kafka's bird. Listening to its song, one may learn not only about birds but also their cages.

This essay is, therefore, intended as a contribution to a history of files. Unlike most of the papers featured in this special issue, it does not look at bureaucratic practice in non-Western contexts or in early modern times. Instead, this contribution hones our understanding of one of bureaucracy's famous homelands: Prussia in Weimar culture to its collapse in 1945. I argue that the emergent rationality of bureaucratic institutions resonates with the intellectual work and administrative
Meisner. His historical and bureaucratic practice was informed by his notion of Prussia as a living bureaucratic paper organism, both past and future. Along these lines, intellectual and administrative work can be understood as modes of subject formation that were coevolving with a particular political stance. It might go too far to assume that intellectual work and bureaucratic practice contribute to shaping a corresponding mode of existence. ${ }^{8}$ However, they are certainly elements that build a habitus or mode of subjectification. ${ }^{9}$ This mode of subjectification allows one to carry out anonymous bureaucratic practices and delegate responsibility to the community - be it intellectually, politically, or ethically. Method and the community's sense of good practice, then, for the individual serve as instances of Subjektentlastung, i.e. the deferral of the onus of decision-making from the individual to other instances through a process of referral.

I begin by briefly introducing the author of the first book-length historical and systematic study of files "Aktenkunde. Ein Handbuch für Archivbenutzer mit besonderer Berücksichtigung Brandenburg Preußens" (1935). Secondly, we will encounter Meisner in an unusual situation: as an observer of the pedestrian traffic in Berlin. With this anecdote, I establish the problem of the contingent and changing relationship between everyday life and the bureaucratic existence son file،. Everyday life, I suggest not without a sense of ironic seriousness, is as alien to bureaucratic logic as James Cook and his crew were strange to the natives of Tahiti. I will return to this mutual ethnographic perspective as a problem of double contingency - i.e., successful communication is contingent on how it is received by the other - later on. In a third step, I provide a close reading of a peculiar specimen of Meisner's "Aktenkunde«, namely, Meisner's own copy of his "Aktenkunde« that he used as notebook for years. I will then return to the difference between the inside and outside of bureaucracy and reconsider it as a problem of double contingency. In the context of the case at hand, double contingency refers to the fact that the emergent rationalities of bureaucracy and everyday coevolve according to their own idiosyncratic logics; even though they sometimes serve as resources for each, they ultimately remain black boxes. In conclusion, I reconsider Meisner's revisions of his book in the shadow of his stance on what he calls political 
revisionism of Prussian historiography on World War I. This will allow me to show how the work of a secondrate scholar transforms into what might be called bureaucratic mediocracy.

Those familiar with the life and work of Meisner may skip the following section and jump right to the section "Intellectual Formation and the Quotidian In and Out of the Archive«. For some readers, however, it may be helpful to establish briefly who the author of the first "Aktenkunde» was.

\section{Heinrich Otto Meisner and the Modern Diplomatics of Files}

To this day, Meisner's "Aktenkunde" remains the standard reference for the history and theory of files. It is also the founding document in the field of what, in English, is known as "modern diplomatics «. ${ }^{10}$ Traditional diplomatics is concerned with medieval documents, namely, charters (Urkunden), whereas modern diplomatics deals with a new form of paperwork that, in large part, only became common in the 16th century, i.e., files (Akten). This distinction is crucial to the project at hand since it allows us to establish the very object under scrutiny and define the subject matter of Meisner's study. ${ }^{11}$ Before Meisner's seminal book, the diplomatics of files was a marginal subfield of traditional diplomatics (Urkundenlehre). Attention to the particular logic of files only fomented in the late 19th century. This followed a mid-19th-century shift in the ways in which historians were conceptualizing history: namely, their increasing preference for files (Akten) over charters (Urkunden) as historical sources. While Leopold Ranke (1795-1886), for instance, preferred narrative documents that already suggested a sequence of historical events and provided a contemporary explanation, his rival Johan Gustav Droysen (1808-1884) championed the study of historical processes documented by files and their specific internal logic. The fact that files documented a process of decision-making rather than results of political and legal decisions allowed the historian to trace the unfolding of events in a different way. Other than in the English bureaucratic system, the German system does not distinguish between records and files. generate files. ${ }^{12}$ To readers of Cornelia Vismann's (19612010) media history of files, Meisner and his book may be familiar. Some of her arguments actually even build upon Meisner's scholarship. However, the lesson we can learn from the example of Meisner's lifelong interest in archival terminology and the language of bureaucracy is that the ways in which administrators and archivists around the globe refer to the objects of their everyday practice varies. ${ }^{13}$

Until the fall of Prussia in 1945, Meisner was one of the leading archivists and historians of the Prussian state. Born on April 1, 1890, in Berlin, he died on November 26, 1976, in Potsdam. ${ }^{14}$ From 1908-1913, Meisner studied history at the Friedrich-WilhelmsUniversität in Berlin. He studied with the following people: the renowned historian of administration, Otto Hintze (1861-1940); the specialist in diplomatics, Michael Tangl (1861-1921); the military historian and conservative politician, Hans Delbrück (1848-1929); and the most prominent proponent of the German historical school of economics and conservative social reformer, Gustav Schmoller (1838-1917). During his studies, Meisner also served as research assistant to the medievalist and legal historian Karl Zeumer (18491914). Meisner wrote his dissertation on "Die Lehre vom monarchischen Prinzip im Zeitalter der Restauration und des Deutschen Bundes" (Breslau 1913). The dissertation was a study of the body politic arguing that the monarch was only legally invested in the authority of the state but did not embody the political authority of the state as Staatsgewalt. ${ }^{15}$ In 1913, at the dawn of World War I, Meisner entered training for archival service in the state archives in Stettin and successfully completed his apprenticeship before the war. ${ }^{16}$ In 1914, he joined the army. Meisner belonged to the generation of combatants called Frontkämpfergeneration. ${ }^{17}$ However, he did not fight at the front nor did he see the trenches of the battle fields. Instead, he served in the office of the German General Staff - obviously with enough time and resources to publish a series of brief articles in what at the time was considered a "national-liberal " journal. ${ }^{18}$ Although these early writings aimed in tone for a considered impartiality, they nonetheless revealed their author as a conservative Prussian nationalist. I will return to this body of texts in the concluding section of this article. 
In 1919, Meisner joined the staff of the Prussian Privy State Archives as assistant archivist. Two years later, he was named state archivist. From 1922 onward, he taught in the training program of the Prussian Privy State Archives, including the course on the diplomatics of modern files. From 1925 to 1928, he was head archivist of the BrandenburgischPreussisches Hausarchiv before he was sent to Moscow and Leningrad, where he studied the organization of the Soviet archival administration. ${ }^{19}$ After 1945, this expertise would help with the denazification process and allow him to move into an important and strategic position in the archival administration of the German Democratic Republic. In the 1930s, however, Meisner became an upstanding citizen of both the German and the international community of archivists and was promoted to the position of lead archivist and deputy director in the Reichsarchiv, which had been founded in the aftermath of the negotiations at Versailles.

The Reichsarchiv was tasked with managing the files of the German Reich, in particular, the military records of World War I. ${ }^{20}$ Under the lead of director Albert Brackmann (1871-1952), the Prussian archival administration and archival science turned aggressively political. In 1929, Brackmann called German archivists to join the "defense battle (Abwehrkampf)" against Poland. Prussian archivists were supposed to learn Polish. His deputy directors, Ernst Zipfel (1891-1966) and Meisner, supported Brackmann's position. Already in the late 1920s and 1930s, the politics of Prussian elite archival institutions was aggressively expansionist. ${ }^{21}$ One of their goals - achieved during World War II through the Nazi regime's strategic plundering - was the acquisition of archival materials on the other side of the »Polish corridor ${ }^{22}$

Meisnerwas not an ardent Nazi. In fact, hewasnot only "a Prussian and remained true to his colors «, but he was in conflict with Nazi party members in the Reichsarchiv. Even though he had joined the party in $1937,{ }^{23}$ Meisner was critical of the rapid rise of party members up the administrative ranks and resented their smug superiority. This institutional configuration produced a contingent social situation that made straightforward attempts of career advancement a long shot. Meisner's colleagues considered him ambitious, slick, and condemned him for not being a true soldier since he had not fought in the field. While he attacked them because their careers in archival administration were facilitated by party politics, rather than intellectual reputation or expertise, they disapproved of his academic attitude. He was an ambitious intellectual bureaucrat, who believed in administration based on archival science, not party association. Still, even though this prevented Meisner from becoming Brackmann's successor as director, he got involved - both intellectually and administratively in the archival politics of the Nazi regime. Before I move on to Meisner's "Aktenkunde«, I want to establish how the emergent rationality of archival science and administration could also organize the perception of everyday life, using Meisner as an example.

\section{Intellectual Formation and the Quotidian In and Out of the Archive}

One day in the 1920s, a thought about the traffic in Berlin crossed the mind of a Prussian archivist. In a short commentary for a conservative daily newspaper, Prussian archivist Heinrich Otto Meisner vivisected a mundane moment on the street of the capital city with bureaucratic rationality. Like many of Meisner's articles in the 1920s, the piece was published by the Berliner Börsen-Zeitung. In his role as an archivist, Meisner strove not to lose himself over the details of a single handwritten document since each individual piece of paper was part of a much larger bureaucratic paper organism. In his gloss on Berlin traffic, Meisner similarly demanded that the individual not get lost in the crowd. In Meisner's ideal world, every single person was supposed to follow the laws of efficiency. On this particular day, he most likely was on the way from his home in Dorotheenstrasse to the Hausarchiv in BerlinCharlottenburg. We don't know for sure which day it was because the newspaper article was literally taken out of context by its author, who kept the clipping as part of his private papers. He cut it out and carefully glued it to a piece of paper before filing it with his notes, excerpts, correspondence, and manuscripts. ${ }^{24}$ By unpacking this box of Meisner's literary estate, I will show how 
the logic of Meisner's intellectual work followed his understanding of Prussian bureaucracy and, again, in which ways the history of bureaucracy unfolds in Meisner's thinking as a historian of administration.

A common impression today of streets in Weimar Germany is that they were populated by innumerable Benjaminan and Kraucauerian flaneurs. ${ }^{25}$ Meisner, on the other hand, was not strolling aimlessly but was looking for the most efficient way to get from point $\mathrm{A}$ to point B. Under the unsuspicious title »From Greater Berlin. Time is Money«, Meisner shared his observations of the street life in Berlin. Against Meisner's intention, I suggest that we can read these passages as ethnography avant la lettre. The bureaucrat on the street gazes at the indigenous Berliners passing by as if they lived on another continent. "Day after day, already for weeks, one has not been able to ignore the same scene at the platform for long-distance trains at Berlin Alexanderplatz. On its East end, we spot an exit-sign above the staircase. That is to say, this exit no longer is an exit but just an entrance." He calls this initial observation a "semantic change" in the urban sign system. The railway management wanted to indicate that something had changed and added a tiny sign "No" next to the exit-sign. " Since the smallish grey-in-grey sign, even with good eyes, is barely legible from a distance and everyone keeps looking at the bigger one with its bright black-on-white letters that continuously shouts its original message into the world, the following occurs: About half of the passengers getting off the train are magnetically attracted by the 'Exit` and move along the platform eastwards." Those passengers were obviously headed in the "wrong" direction. All the efforts of the conductors to redirect the crowd failed, and people unwillingly took a detour and lost time. Many had shared one of these moments of confusion with Meisner, but no one else was eager to become its chronicler. Meisner's trained eye as archivist, however, paid attention to both individual detail and the rationality of the larger whole. He was upset about the everyday chaos in the streets, which ran counter to his striving for maximum efficiency and precision. The gaze of the archivist provided a backdrop that staged an everyday moment in different light. According to the logic of efficiency, the result of this situation was devastating: "The detour imposed on steps or seconds. Accordingly, the daily total time loss is the result of this number multiplied by the number of passengers, which was recently considerably increased by new suburban trains."

This resonates clearly with Max Weber's observation from the early 1920s that "it would be sheer illusion to think for a moment that continuous administrative work can be carried out in any field except by means of officials working in offices. The whole pattern of everyday life is cut to fit this framework « ${ }^{26}$ The clear-cut distinction between the everyday and bureaucratic life collapsed in Meisner's gloss. A mix between rational efficiency and discipline filtered the perspective on everyday life before the "residues of past life«, as Meisner once termed it, could enter the archives: administrative act after administrative act, file after file. What one could find in the archives of the Prussian state were not quotidian occurrences, but the papery existence of the citizen. Only that which could be translated into the language of bureaucracy could enjoy an afterlife in the archives.

What surfaces in Meisner's anecdote is what Weber called "formal rationality", i.e., a practice of efficiency and discipline that aims to guarantee "frictionless" bureaucratic administration. Bureaucracy, Weber claimed, is the purest form of legal domination: efficient, fast, and predictable. Whoever was invested in a position of authority - in the case of the Prussian archival service, by taking a bureaucratic oath ${ }^{27}$ - has the right to issue commands and, one should add, delegate responsibility. It is, however, not the person but the law itself that is to be obeyed. This investiture defines a particular subject position within the "rational state» that removes the individual official from what Weber called the "means of administration «. ${ }^{28}$ This strong sense of duty made the bureaucrats "carry out their work in a precise and impersonal way, with a minimum of feelings «, ${ }^{29}$ a cliché that certainly applied to many Prussian officials, including Meisner, who was praised by his colleagues for his sense of grounded objectivity (Sachlichkeit). It is important to add that objectivity is driven by affect. It does not come naturally but is driven by desire. Occasionally, Meisner's sachlich attitude was, and still is, misread as neutrality to the extent that the political implications of his thinking are overlooked and his yearning for objective historical realism is taken at 
face value. Yet, the opposite was the case: Sachlichkeit for Meisner certainly also served as means to political ends and was used to conceal a political agenda.

The two bodies of the public official were paralleled by a spatial separation of home and office: »the modern organization of the civil service separates the bureau from the private domicile of the official and, in general, segregates official activity from the sphere of private life «. ${ }^{30}$ This separation had an impact on the individual subject's formation and was structurally homologous to the split between quotidian and bureaucratic existence. Consequently, this suggests a divide between the two personae that can analytically be distinguished although they indeed serve as resources for each other in everyday practice. The everydayness of intellectual and administrative work eventually has to be denied and excluded in order to enable the particular logics of these discourses to unfold. ${ }^{31}$ Yet if we want to understand knowledge in the making, it is essential to attend to everything that is at hand and thus can become a resource for knowledge in nuce. In the archival world this notion is called the "principle of provenance«. Since the late 19th century, it had replaced the systematic classification of archival materials by topics with a theory of their original order as it was shaped by administrative procedures.

The split between home and office, private and public personae of the official, extended further to the differentiation between administrative and intellectual work of archivists in public service. This division helps to explain why archivists, who usually were trained historians, had to do historical work on their own time. During working hours, this kind of research was limited to the kind of historical knowledge the organization of archival documents demanded. ${ }^{32}$ As state archivist, Meisner was one of those officials performing both administrative and intellectual work inside the papery organism of Prussian bureaucracy. His trained eye made visible the logic of the filter that bureaucracy used to conceive of everyday life. By no means were state archives preserves of past social lives. What they embodied was a very particular notion of the self-realization of the state founded on the rule of law and governed by bureaucracy, whose history was shaped by paper organisms that would turn into administrative circulation. This notion of the past as self-realization of the historical process may well be called spontaneous history. This spontaneous history is nothing but a variation on the spontaneous philosophy of the Prussian "historian-archivist" and his implicit epistemological and ontological assumption about the bureaucratic perception of the past. In the logic of the administrations of the modern Western world, "a life without files, without any recording, a life off the record, is simply unthinkable . $^{33}$

Again, Weber's historical sociology of the "management of the modern office«, which was "based upon written documents (the 'files`)«, makes clear why its "staff and subaltern officials and scribes « were intrigued by Droysen's history-based-on-files notion. What Droysen called the "Niederschlag" of historical events, which often took the form of files, is only partly translated by the English term sprecipitation $\times{ }^{34}$ Niederschlag implies that scattered events stream down like rain showers, leaving traces of a climate of the past, i.e., longue durée averages of weather phenomena that also create a social atmosphere. This climate was mediated by a strong sense of the political success of Prussia.

Both Droysen and Meisner, as well as many others, espoused the notion that a particularly Prussian mode of writing history constituted the ideal and paradigm of their thinking. This was one of the prerequisites of Meisner's intellectual formation. In many ways, he followed in the footsteps of Droysen's understanding of history as "forschendes Verstehen " while working with bureaucratic discipline to show that "what happens all around and to us, what is it other than the present of history, the history of the present « ${ }^{35}$ They both agreed that this history of the present had to be revised occasionally. Yet, this is not to be confused with a plea for a necessary rewriting of history. Rather, it was a claim to support an aggressive political agenda of Prussian hegemony - as I will detail in the final section of this article: "The German question is not a constitutional question, but a question of power; and the Prussian monarchy is now wholly German, while that of Austria cannot be.«36 In his 1930 article, Meisner takes an even more explicit approach on the matter. Under the title "Revisionismus«. A Defense", he argued for the necessity of the hegemony of Prussia 
and the preservation of a "strong central power (starker Machtkern) for any future Germany «. ${ }^{37}$ He attacked the political revisions in the aftermath of Germany's defeat in World War I. These revisions of German history put at stake what was at the core of his understanding of Prussian history and its present. ${ }^{38}$

\section{Revisions in Original Order}

The way Meisner observed everyday life in Berlin and Prussia, makes clear the bureaucratic logic that facilitated his intellectual work in the archives. Meisner's understanding of Prussia resonated in the everyday practice of his intellectual work. Accordingly "Aktenkunde" divulges these ideas with the following disclosure: "The paradigm«, of this book, states Meisner, »is Brandenburg-Prussia «. ${ }^{39}$ According to him, this example was particularly well suited to show the very rationality of government by files since Prussian chanceries and offices were places of »strict discipline«. The rigorous regulation of bureaucratic practice and the rational stance of Prussian officials shaped their administrative procedures. They, therefore, reached "a remarkable level of uniformity «. ${ }^{40}$ This, for Meisner, was a way to legitimize the narrow scope of his study. Prussia served as a historical example and prescriptive model of analysis.

Meisner's "Aktenkunde" grew out of the lectures he had delivered at the Prussian Institut für Archivwissenschaft in Dahlem, Berlin, ${ }^{41}$ since 1922 while working at the Prussian Privy State Archive as lead archivist. ${ }^{42}$ These lectures were supposed to introduce novice archivists during their training on the job. Many of them held a doctorate in history and thus were familiar with the basics of the auxiliary sciences of the historical discipline: paleography, sigillography, numismatics, and so on. Traditionally, the focus of the auxiliary sciences was on medieval and early modern materials. This remained true through Meisner's days as a student. In 1909-1910, and again in 1912, he had taken courses with one of the experts in the field, Michael Tangl. ${ }^{43}$ Tangl was trained at the Institut für Österreichische Geschichtsforschung, the local center for diplomatics, comparable to the École des Chartes historical discipline. ${ }^{44}$ Since the days of Theodor von Sickel (1826-1908), the Vienna school had - in contrast to diplomatics in Germany - taken a turn toward the critique of nonnarrative sources. ${ }^{45}$ This is relevant insofar as files fall into the latter category.

Meisner's notes from Tangl's lectures are neat and meticulous. ${ }^{46}$ From the notes, it becomes evident that Tangl's approach may very well have inspired Meisner's thinking about a diplomatics of files. Just to give a glimpse into the basics of Tangl's teaching based on Meisner's notes ${ }^{47}$ : "Geisteswissenschaft « could only operate through the mediation of writing. The critique of sources, therefore, was essential also because writing was the "expression (Ausdruck)« of the art of its time. Furthermore, he attended to the materiality of written matter. He insisted, for instance, that there was a correlation between the devices (Schreibstoff) and the form (Schriftart) of writing. It has "developed organically" and therefore should be treated historically, not systematically. ${ }^{48}$ Ultimately, Meisner's teaching, combined with his years of practice as both historian and archivist, became the basis of his work in the diplomatics of modern files, which acknowledged the importance of nonnarrative sources in critical terms and shed new light on the government by bureaucratic paperwork.

The organic aspect of the logic of files was particularly important to his study because it framed his thinking about files and filing in a specific way. Meisner pioneered the study of modern diplomatics when he wrote the first systematic book-length study of the subject. In keeping with traditional good practice and common sense in diplomatics, the book falls into four major sections: (1) the "terminology" of files, (2) a systematic account of the different forms of files, (3) the "analytical « critique of the "internal " and "external " characteristics of files, and (4) the "genetic" Aktenkunde that traces the "life" of files through the "three zones, namely, chancellery, registry, and archive ${ }^{49}$ Modern diplomatics of files, to this day, remains structured accordingly into a threefold approach: analytic, genetic, and systematic. ${ }^{50}$ Ultimately, the goal of the "Aktenkunde« was to provide a manual for users of archives and the materials they hold and to contribute both to the history of administration and to the canon of the auxiliary sciences of the historical discipline. 
Meisner's interest in the diplomatics of modern files, however, did not conclude once he had published the "Aktenkunde». In fact, he used a copy of his own book to take notes, add materials, and to revise some of his earlier positions. With this copy of Meisner's "Aktenkunde" at hand, I want to ask a rather simple question: How did Meisner use his own book to organize information? The answer to this question requires some preliminary remarks about the object of Meisner's reading. The case in point is a copy of Meisner's own "Aktenkunde«. It deserves attention because it embodies the bureaucratic logic and historical thinking of Prussian archival science - as we have first encountered it with the street anecdote - in exemplary form. The material form, indeed, matters here in particular since Meisner's copy of his own book is peculiar. Following a quite common intellectual practice that persisted until the mid-20th century, he had the book rebound with blank pages between each printed page to create space for his annotations. This practice of note-taking reflects the very logic of the archival documents it set out to describe.

Meisner refrained from keeping notes in a journal, in a notebook, or on cards organized in a box. He did not create thematic dossiers but insisted on placing his thoughts and comments where they belonged, namely, their place within an »original order». This is not only true for his "Aktenkunde" but also for several other texts, including his own or those of others that manifest an interest in this specific mode of ordering information; among his papers, we find restlessly annotated copies of his own archival terminology as well as Adolf Brennecke's "Archivkunde«, to name just two examples. What those copies all have in common is the logic they use to organize information. This logic submits to tradition and acknowledges provenance as the determinant ordering factor. That is to say that the original organization of materials determines how it is classified, i.e., papers are not reorganized by archivists according to a system of classification but kept in the organization in which they are received from the administrative body. Every single operation of keeping things in what appears to be historical context is nothing other than the ex post facto creation of what is assumed to be the original order. We see this today when we
Page after page, we discern how this process unfolded on a material level. Accordingly, in examining the material object, we become well acquainted with how the bureaucratic institution thought and how this thinking informed the intellectual work of its officials. ${ }^{51}$ This practice of intellectual work was shaped by the institution, but not entirely contained by it. It extends beyond institutional limits. It spreads over, it imbues the subject's worldview from everyday practice to ethical or political stances. Moreover, this goes both ways. That is to say, the subject's sociocultural disposition can be mobilized as a resource for intellectual work in similar ways as the institutional thinking contributes to the subject's own formation.

Meisner's method of note-taking could not have been more alien to the kind of systematic data management emerging at the time. While German bureaucracy was restructured by the so-called office reform ${ }^{52}$ and the notion of a universal classification of knowledge that had begun to find institutional form ${ }^{53}$, Meisner followed a long-standing tradition of scholarly reading that came out of early modern intellectual traditions. Historians of the book and of scholarship have described this practice of early modern reading as follows: As numerous examples in manuscript collections around the globe ${ }^{54}$ show, readers liked to deface books with their learned comments and marginalia. ${ }^{55}$ Those notes and scribbles were signs of appropriation and full intellectual commitment to a text and its subject matter with extreme proximity and little sobjective distance This was no longer common practice at the beginning of the 20th century. Yet, there are many examples of the continuation of this learned tradition of wild reading and intellectual messiness, be it philosopher's marginalia or historian's reading notes. ${ }^{56}$

It seems important, however, to keep in mind that Meisner's reading practices ran against a general trend. Many scholars relied on a different tradition of neat data management that was supported by lowfi technology from library science, which had entered office management. Even though these devices, most importantly the card catalog, go all the way back to early modern library organization, they received new attention at the turn of the 19th to the 20th century. ${ }^{57}$ Through a transfer of technology and knowledge from Europe to the United States and back again, as Markus 
Krajewski has shown, the economy of paper machines, such as the card catalogs, shaped a novel form of preelectronic data processing. ${ }^{58}$ These card catalogs were precisely the sort of efficiency tools that Meisner, ironically, did not adopt, which is surprising given the premium he placed on rational organization.

One example for this more general trend of the early 20th century will illustrate the differences relative to Meisner. In 1921, the philosopher Friedrich Kuntze published his widely read »The Technique of Intellectual Labor ${ }^{59}$. This essay takes the reader to a trade fair for office supplies and devices, a Büroausstellung. "There, I saw in an overwhelming assembly of useful aids and often genius methods of organization that the modern businessman had created and held them against my own - the traditional - unpractical working methods. « ${ }^{60}$ He was particularly intrigued by the card catalogs. Thus, from this moment on, he started working on adapting these techniques of office management to the practice of intellectual work. Following the economy of Taylorism, his goal was to identify single steps of the intellectual working process - absorb, organize, produce, ${ }^{61}$ - and make sure to systematically control every move a scholar needs to take. What 19th-century humanists had already denounced as factory-like intellectual work had become a new ideal in the early 20 th century. The benefit of this practice was supposed to lie in its independence from individual scholars and single minds. Data management was intended to have the following features: be reproducible and descriptive; generate meaningful metadata; and, last but not the least, submit the scholar to a rational, effective, and responsible work ethic. In other words, the new techniques of management were supposed to channel the "wild streams « of intellectual work. ${ }^{62}$

If one opens the archival copy of the book (see Fig. 1), it can be observed that Meisner did not use these new techniques of information management as they became very popular in library science but preferred to resort to the logic of archival provenance in order to organize his notes. Looking at the pages of his copy, it becomes clear that this was a project carried out over a period of 2 decades. This particular copy is more than twice as voluminous as the original book in print. Meisner had not only bound an additional blank page between slips with notes on top of the blank pages with his annotations, added loose leaves with notes, or inserted clippings from newspapers and journals; one can find, for instance, a review of Leo Santifaller's (1890-1974) »Urkundenforschung ", published in $1937 .{ }^{63}$ Eventually, he used his annotated copy of the "Aktenkunde" to prepare his more comprehensive "Urkunden- und Aktenlehre der Neuzeit", first published in 1950 and reedited in 1952. The latter replaced Meisner's first attempt at a handbook of modern diplomatics. ${ }^{64}$

Turning the pages of this book affords a glance at Meisner's fixation with accuracy and precision. His copy of the "Aktenkunde" indeed served as a peculiar system of note-taking that kept local knowledge in place. Yet, his passion for exactitude was a messy process. New facts and figures did not come neatly packed. They had to be taken out of context and inserted into a new place within the logic of the "Aktenkunde» as it stood. This resembled Meisner's understanding of archival knowledge: archives, according to him, were organized following the logic of historically situated knowledge, a notion that he also reflected in his writings on archival terminology and the language of archives. In short, his thinking - which very much is aligned with the commonsensical disposition of the German-speaking archival profession - goes as follows. First, modern archives emerge from bureaucratic paperwork; they do not collect but "grow organically «. Second, the history of the German nation is a history of a federal organization in local states. Therefore, their particular histories and the local use of archival languages require attention. Third, archives and the materials they contain are to be organized according to the principle of provenance. At the time, German archivists followed two main interpretations of the principle of provenance, namely, the "free principle of provenance and the notion of an "archival body«.

This can be shown with another heavily annotated book in Meisner's archive, Brenneke's "Archivkunde«, (Fig. 2), which was based on his lectures and only published posthumously. For Meisner, it pertained to the matter of "Aktenkunde». At least, we find a review by Berent Schwineköper (1912-1993)65 of Brenneke's book as part of Meisner's notes on the modern diplomatics of files. The necessary attention to the concrete and to particularities made a general theory of 


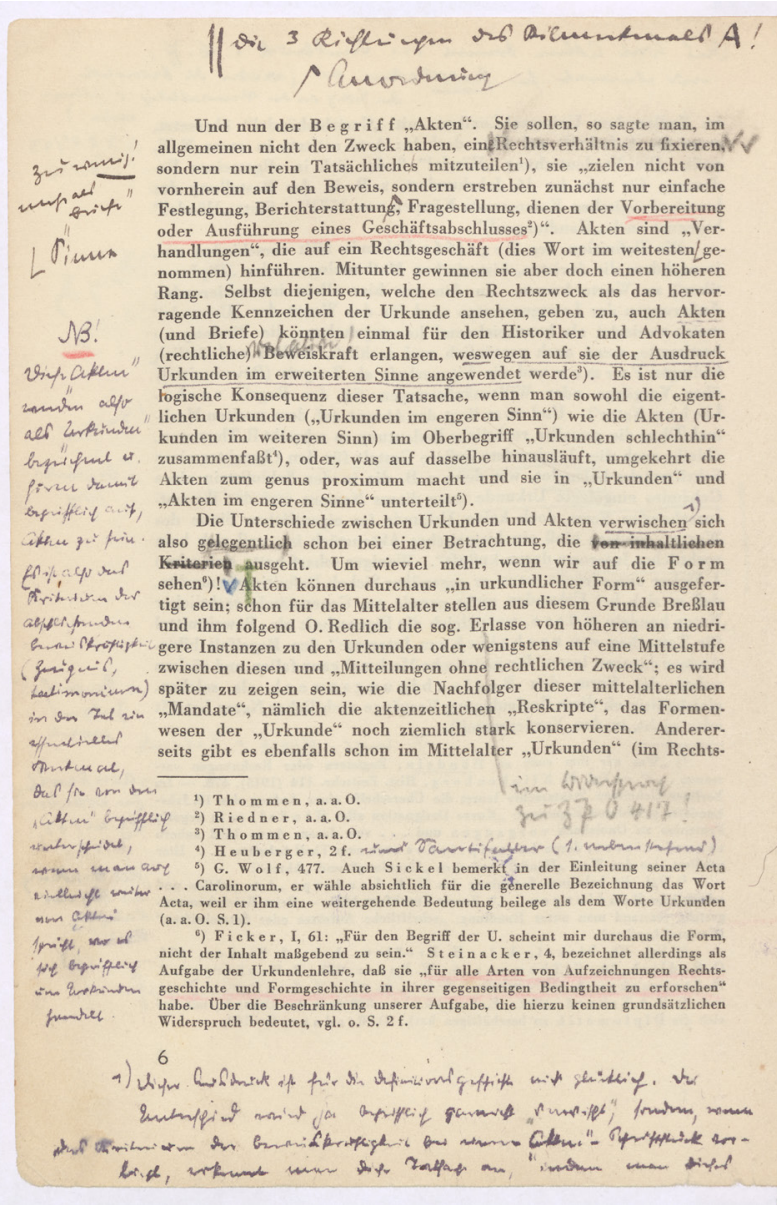

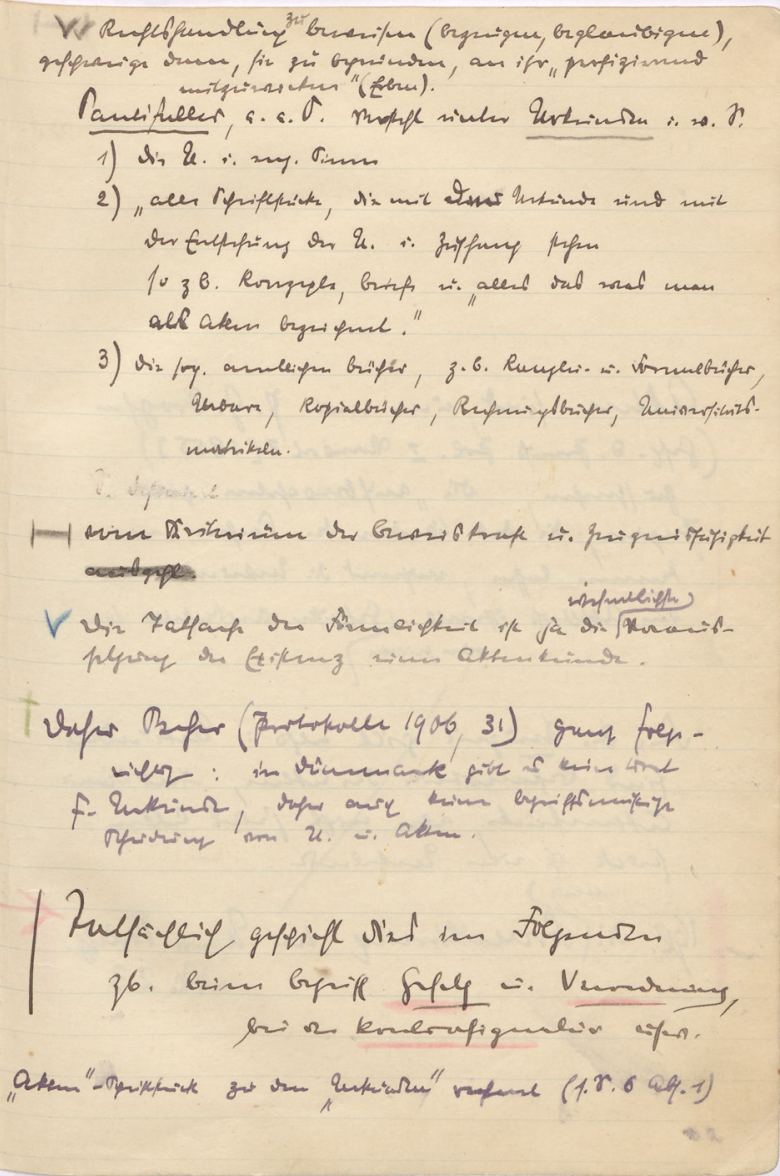

Figure 1: Page 6 of Meisner's annotated „Aktenkunde» and the blank page with his notes, BBAW NI. H.0. Meisner, no. 159.

archives challenging. Meisner and his colleagues now considered Brenneke's lectures finally the foundation of such a general theory. What was most important about Brenneke, as Meisner emphasizes in the margins of the review, was that he succeeded in demonstrating the tight connection of the internal and external forms. Meisner's own review of the book in the Deutsche Literaturzeitung acknowledged Brenneke's presentation of the rise of the principle of provenance against the earlier positions of the so-called "Pertinenzler" (followers of the principle of pertinence) and "Methodizers" (followers of a systematic classification of archival materials). Yet, Meisner strongly disagreed with Brenneke's notion of a "free principle of provenance«, which would have allowed for the reconstruction of the original order based on an idealizing projection of its original form without attention to the actual material form of the body, for Meisner, was plastic, not elastic. ${ }^{66} \mathrm{He}$ preferred the phrase "principle of organic structuring " since he considered archival materials as paper organisms that embody a plastic notion of history and historical time, reflecting a Hegelian understanding of the nation-state and its history.

Turning to the next pages, we see also that the table of contents was heavily revised. Some chapters deleted, with others added, restructured, or updated (see Fig. 3 and 4). One may assume that Meisner, at an earlier stage, had aimed toward producing a new edition of his book. The revisions on the table of contents suggest that he might have ultimately realized that what he initially thought would be a reedition actually would turn out to be a new book. This book ultimately materialized in 1950 as "Urkunden- und Aktenlehre der Neuzeit». The bibliography is updated, with new literature being added and some discarded as no longer being 


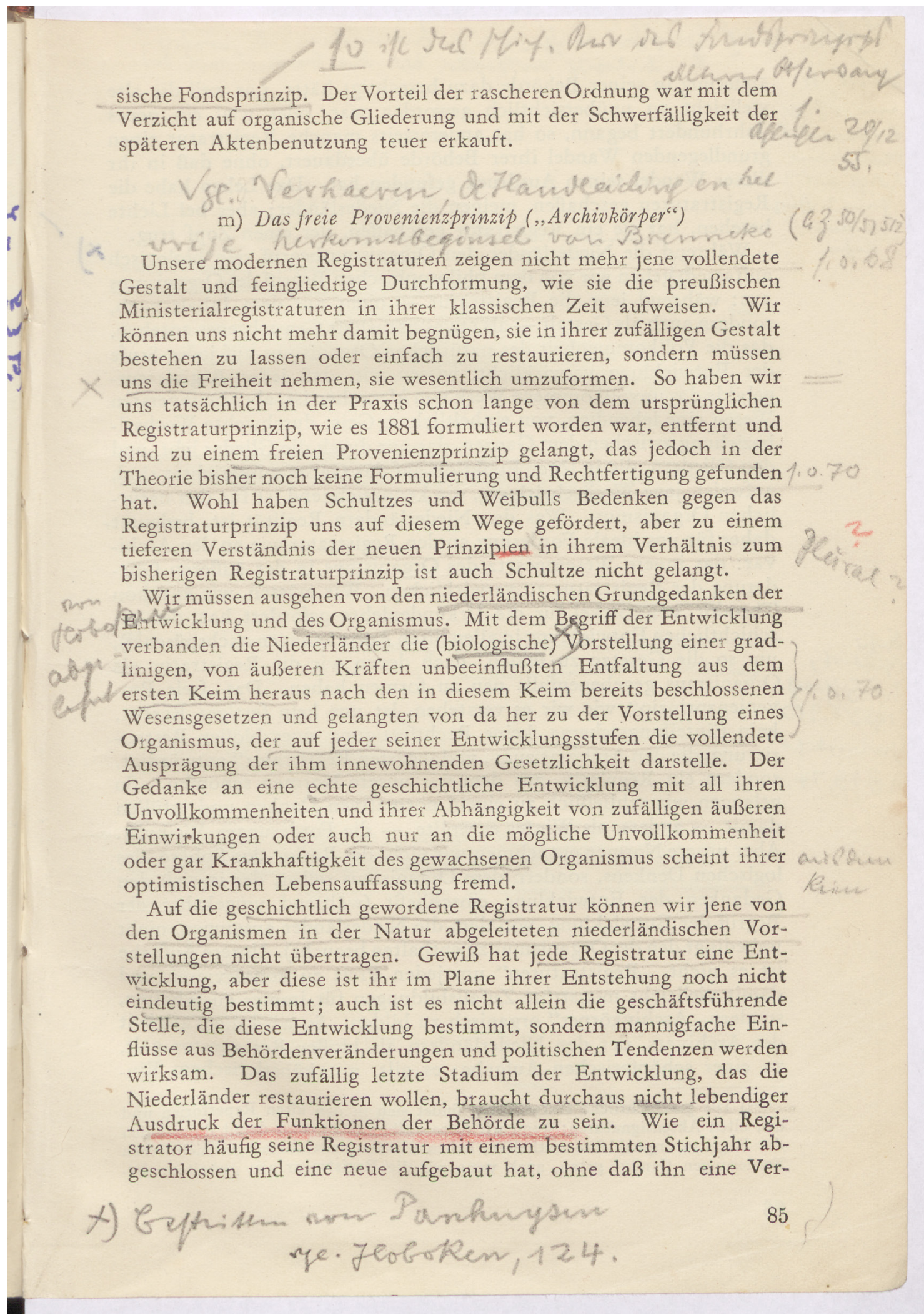

Figure 2: Page 85 of Meisner's annotated copy of Adolf Brenneke's "Archivkunde: ein Beitrag zur Theorie und Geschichte des europäischen Archivwesens«, Leipzig, Koehler U. Amelang, 1953, BBAW NI. H.O. Meisner, no. 159. 
relevant. Furthermore, Meisner's attention to detail was painstaking. A note attached to the register ponders the question whether one should use "v. or von « in the index of the book. Throughout the printed pages of the book, we find simple corrections, such as "Stärke» instead of "Stücke» (p. 11), or stylistic author revisions, such as a deleted »dabei« (again p. 11, note 2), or - in an attempt to ensure more clarity - he uses "Hülle« instead of "sog. Schürze« (p. 11) to describe the binding of files into material units. Meisner's theoretical ambition often was at odds with the desire for clarity and concretion. The simple statement, for instance, on page 11, »originally the Brandenburg-Prussian archivists called a package of files (Aktenpaket) a convolute", is annotated with "What did this look like?«, and above, he added, »convolute = Aktenpaket... ${ }^{67}$ This, in fact, was a simple but good question he pursued also in a more general fashion. In the margins of his annotated "Aktenkunde", he gives an answer to his question about what these objects looked with reference to the literature in which he learned about them, e.g., the notion of "true colossals of bundles of files up to one meter deep " is annotated with »Cf. Innsbruck. S. AZ 42/43, p. 105 ,1000 sheets thick «". In the pages that followed, Meisner outlined a completely revised section on "systematic Aktenkunde«. A brief note to himself reminds him to include relevant new legislation since 1918. However, the task of the diplomatics of files seems not to have changed for Meisner. No single revision in the first couple of lines. In my English translation, it reads: "Who came in touch with the source materials of more recent centuries will miss the kind of lead that the medieval diplomatics provide since the days of Jean Mabillon (1632-1707). The reasons why the formal Erschliessung of files was not in sync with the opening of the archives are of varying nature. That which saw the day of light in the offices of scribes remained mostly hidden to the public. Even though legal directives were disseminated in print and later became easily available through special collections, one could, for instance, study the history of the forms of the royal order (herrschaftlicher Befehl) or the issue of countersigned signatures with materials at hand for practice. ${ }^{68}$

Besides these kinds of pragmatic obstacles, there was another issue that slowed down the "development of diplomatics of modern files: the disregard of files themselves«. ${ }^{69}$ This was both true for their lives and afterlives. The administration did not quite know what to do with the masses of paperwork, and the archives were also not fond of this kind of document. Until the early 19th century, some archivists argued that files were supposed to be excluded from the archives altogether. While, throughout the 19th century, the reputation of files improved, the diplomatics of modern files did not become a priority. The focus was still on medieval materials, and files were considered just a particular group of documents within the larger family of Urkunden, i.e., charters and similar kinds of legal instruments in writing - usually signed, sealed, or otherwise attested.

Using a common practical typology, one might say: While files (Akten) document a process of decisionmaking, charters (Urkunden) typically record legal verdicts. Accordingly, Meisner argued that medieval documents are characterized by family resemblance, while modern files are diverse: As the Holy Roman Empire dissolved into a complex system of nation-states and territories, the growing number of chancelleries and the increasing diversity of paperwork they produced engendered a "written precipitation of incomparable abundance and variegation «. ${ }^{70}$ On the right blank page, Meisner comments that the diversification of modern files »re: individuality, with files requires physiognomic form". He also refers to an important topos going back to 19th-century Prussian historiography, namely, Droysen. "Files are, to speak with J.G. Droysen (Gesch. d. Preuß. Pol. I [1855]), the polit[ical] wittnesses that allow to recognize the coming into being of matters at hand while charters only allow a glimpse at the sealing of a transaction.« (cf. Fig. 2).

The section on the distinction between Urkunden and Akten reflects Meisner's ongoing involvement in the language of archives and an international terminology of archival science. ${ }^{71}$ Here, the annotations barely leave any space in the margins; too many additions and revisions, along with numerous corrections and exuberant highlighting, revise the printed text in many important details. The line of argumentation, however, is hardly changed. Meisner sticks to his earlier outline. On page 7 , for instance, he revisits a quotation from the Swiss historian and scholar of diplomatics Rudolf Thommen's (1860-1950) »Urkundenlehre «72: Thommen 

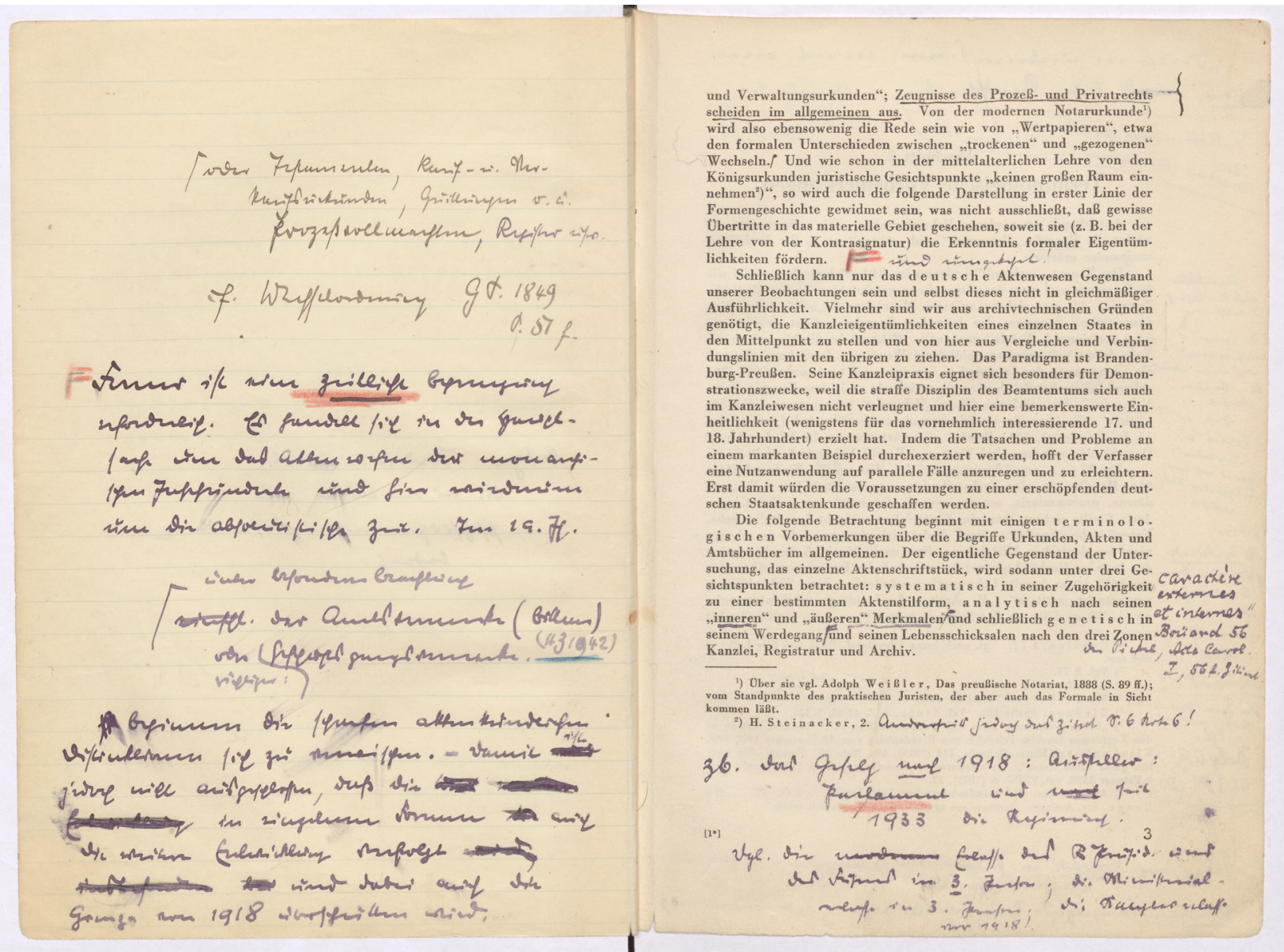

Figure 3: Page 3 of Meisner's annotated "Aktenkunde» and the blank page with his notes, BBAW NI. H.O. Meisner, no.

159. The system of color-coded highlighting was something he already used in his notes from Tangl's lectures. It remains unclear whether its logic was consistent over the decades or was only applied to each text individually. Most likely, the system was rather random and changed from sitting to sitting. What becomes clear from the various items in the literary estate is that Meisner used different pens and pencils for his notes over the decades. Typically, he used whatever was at hand, be it writing utensils or paper. Like many scholars, he often reused pieces of paper.

had maintained that there is a particular type of medieval Urkunden, namely "besiegelte Abschiede«, which shares several relevant characteristics with modern Akten. The passage reads: this kind of Urkunden "have lost all formulaic elements that one may almost count them as files «. ${ }^{73}$ Meisner notes: »Formgesichtspunkt! ,Urkunde` ist Zweckgesichtspunkt. (Aspect of form! `Diploma ‘ follows aspect of purpose.) « Other than Thommen, whose focus was on form, Meisner insisted that materiality matters and those documents were actually Urkunden and could only formally be considered files.

Accordingly, Meisner maintained that files could only be understood within a series of other files, that is "as part of a fascicle» while an Urkunde was "a selfcontained individuality«. Against this logic of seriality, Meisner insisted, however, certain parts of a file could be singled out and also understood as individual documents. Yet again, in reference to an article by the director of the Vienna Haus-, Hof- und Staatsarchiv, Ludwig Bittner (1877-1945), published in the Historische Zeitschrift, he notes in the margins of page 7: "files only lead to a legal transaction, nothing absolute, only relative ${ }^{74}$

Meisner's study in modern diplomatics can be read as a contribution to the question of how institutions think with the help of files. What remains a blind spot 

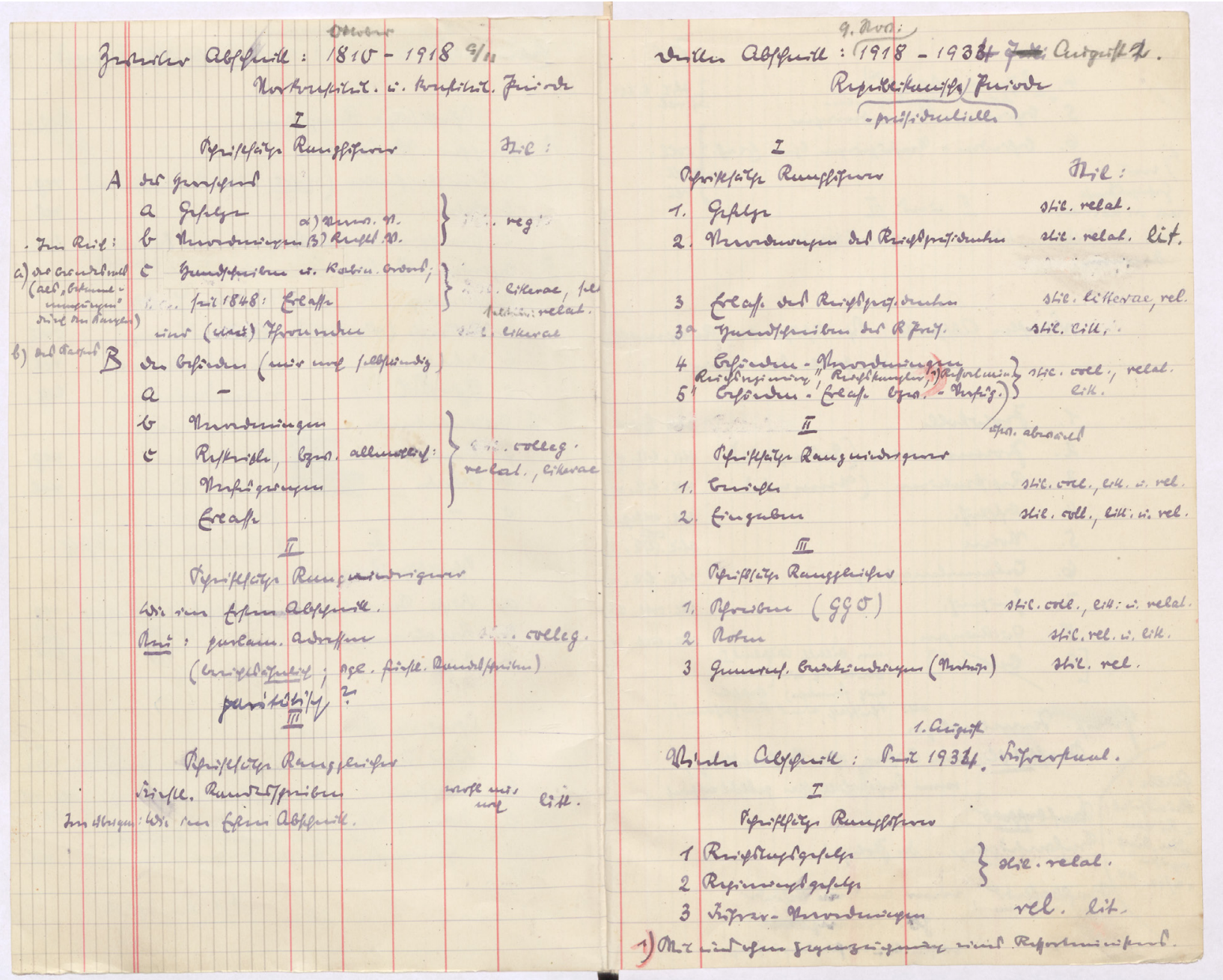

Figure 4: Outline of a revised table of contents, between pages 6 and 7 of Meisner's annotated "Aktenkunde«, BBAW NI. H.O. Meisner, no. 159.

in Meisner's thinking is the question of how everyday life can go on file, i.e., under which conditions does it become possible that our day-to-day life can be recorded by bureaucratic paperwork? With Meisner's case at hand, I suggest that this becomes possible within a model of double contingency.

\section{The Contingency of Emergent Rationalities}

Let me remind you of the anecdote of Meisner's gaze at the pedestrian traffic at Berlin Alexanderplatz station. Picture yet another scene: "On the left, down Münzstrasse, were blinking lights that indicated cinemas. On the corner he got held up, people were stood in front of a fence, there was a big hole there, the tramlines on their sleepers were crossing empty space, just then a tram slowly passed. ${ }^{75}$ One may add: Two strangers walking along the rail platform, the crowd opens up a narrow path; not quite wide enough for both to simply pass by each other but they both have to decide who goes left and who takes the right: In other words, an exemplary situation of what is called double contingency.

First suggested by psychologist Robert R. Sears, Talcott Parsons and Edward A. Shils argued that double contingency was fundamental to any social interaction. It was a way of engaging with the problem of how social organization was possible. They had introduced double 
contingency on the level of individual interaction, such as the random encounter of two strangers in the streets: "On the one hand, ego's gratifications are contingent on his selection among available alternatives. But in turn, alter's reaction will be contingent on ego's selection and will result from a complementary selection on alter's part. « $^{76}$ What is described here as a situated instance of double contingency is to be reconsidered as a pattern of communication and can be generalized in the sense that it determines the structure of a pattern. If we take the issue of double contingency from the example of the encounter of two individuals to the institutional level of the coevolution of two emergent rationalities, e.g., bureaucracy and everyday life, the problematic needs to be reconfigured.

Each bureaucratic institution, or system, works according to its own particular rationality. It is selfreferential and, therefore, necessarily relatively closed to information from outside of the system. That is to say that the bureaucratic institution only can accept information from the outside world that comes in a format that it can process, say through a particular form or accepted forms of paperwork, as a petition, a complaint or, simply as any other input it can process, classify, and incorporate. Even though both bureaucracy and everyday life have practical and tacit knowledge that allows them to deal with each other, the two systems remain black boxes separated from one another. The traces of everyday life are literally boxed away in the archives, where even proper names often are hidden from the networks of archival classification since they may not have been significant for information that was processed by a bureaucratic administration. Anecdotes, like the one I gave at the beginning of this article that showed bureaucracy encountering everyday life directly can usually only be found through hard work or serendipity. They cannot be searched for systematically because the logic of everyday life and the logic of bureaucratic practice refuse to be mapped onto each other. Selection criteria cannot be observed from the outside of the bureaucratic black box, just as it cannot be viewed from outside of everyday life; one has to, for instance, submit to the institutional logic in order to survive without papers, or get a certificate issued. This is the case whether or not one does or does not have an existence on paper in bureaucracy.
In the bureaucratic language of systems theory, the sense of possibility of double contingency is defined as follows: "The being of a given is the result of a selection that defines the not-being as being of other possibilities. «77 In other words, picture an incident step by step. Traces of this incident enter the bureaucratic system or a record thereof enters the archive. There, this incident is documented for posteriority. Any other occurrence that does not enter the system implicitly shapes an ex-negativo space of possibility. That is to say that future historians will rely on the record as evidence and may overlook what happened but did not leave a trace. Clever future historians will, therefore, ask what they cannot find in the archives because it was never recorded. They are aware that they are always dealing with both the contingencies and probabilities of the material tradition. ${ }^{78}$ Some events were and still are more likely to go on record than others and not everything that goes on record is archived. Dealing with the double contingencies between the worlds within and outside the bureaucratic institutions, therefore, requires historical imagination and a sense of possibility of that which remains unrecorded and »outside «. ${ }^{79}$

Anyone, such as Meisner, who travels between two worlds, e.g., the bureaucracy and the everyday, finds himself/herself within the symbolic economy of ethnographic travel. The logic of travel is circular. It takes the subject to the place of the other and back to the point of departure. Therefore, any experience in the place of the other has to be translated upon return. ${ }^{80}$ Taking this circularity one step further, one may think of this place of the other in Foucauldian terms as a heterotopia. ${ }^{81}$ Historical time, as it is embodied in state archives, then "appears to us only as one of the various distributive operations that are possible for the elements that are spread out in space «. ${ }^{82}$ Heterotopias of time break with everyday experience and create places within society where certain social elements are redistributed, that is to say, they are excluded by inclusion. Accordingly, historical time - as it is represented in files that shape a bureaucratic paper organism - is contested and inverted. In that sense, heterotopias mirror what appears as normal in an exceptional way as places "outside of all places, even though it may be possible to indicate their location in reality «83; one might say that they remain obscure, black boxes. These places of the other in their 
own culture, therefore, can only be analyzed with the ethnographic perspective of an "anthropology of reason «. ${ }^{84}$ This applies also for bureaucratic as well as historical reason. In order to understand their function within society and how their logics play out in cultural codes that inform social interaction, one cannot but look at them as heterotopic by nature. Otherwise, any analysis would fail at describing its very logic based on an incorrect assumption of universal hermeneutic understanding.

How can everyday life enter a file? After all, "Quod non in actis, non in mundo«. ${ }^{85}$ Ultimately, double contingency has the effect of resolving and stabilizing. An emergent differentiation then can appear as unalterable difference. Then, the logic of the archive restructures the view on reality in a way that makes it difficult to acknowledge the contingencies of the mundane world outside the archive in their own right. In these cases, the Quod non in actis, non in mundo turns from an epistemological prerequisite into a quasiontological statement about past reality.

\section{Bureaucratic Mediocracy}

Given Meisner's notion of the strict military discipline and frictionless rationality of Prussian bureaucracy, he necessarily overlooked what could not fit into the logic of bureaucratic paperwork. This, yet again, would have been one of the conditions for his aggressive political expansionism in the name of the Prussian State. In his review of what he calls the anti-Prussian revisionism in the aftermath of World War I, Meisner emphasizes that Johann Gottlieb Fichte's (1762-1814) notion of the state lacked the "warmth of the blood of real humans" (»Blutwärme des natürlichen Menschen «). A rejection of the "Machtstaatsgedankens" would miss the very character of Prussia and "smudge " the "harder line« between cosmopolitism and nationstate. ${ }^{86}$ With this, I turn to Meisner's commentary on what he calls "revisionist" historiography. His article on "Staatsanschauung" started out with a motto he had obviously quoted from memory: "We must become wicked sinners if we want to grow «. ${ }^{87}$ This quote from what Meisner called "the modern poet " is from a second-rate writer Hermann Sudermann (1857-1928), who was quite prominent at the time and celebrated in particular for his play "Homeland «. In the play, one of the protagonists, Magda, in fact, says, "Guilty we must become ${ }^{88}$ This indeed could serve as a leitmotif to Meisner's stance toward Prussia. Sudermann was one of the cosigners of the 1914 "Manifesto of the Ninety-Three«, which denied any German guilt for the beginning of the war and declared their support of German military actions as an act of self-defense. ${ }^{89}$ While many of the signers later regretted having signed this manifesto, it served as a political signal when Meisner alluded to it in a piece of scholarship on bureaucratic method after the German defeat.

The question of war guilt in international politics, Meisner argued, translated into a revisionist debate of the historical "calling of Prussia « (a calling to bind the divergent German Volkskörper together ${ }^{90}$ ); this led intellectuals and politicians to revisit the history of Germany in the shadows of defeat. In his opinion, this form of revisionism hurt the principle of impartiality. Against this, he demanded an objective perspective on Germany's world-historical position in what he considered a "play" of the "immanent laws" that had interfered into the habitat (Lebensraum) of the "geopolitically so unfortunately situated " German people. ${ }^{91}$ In his articles, Meisner both historicized and mobilized the metaphorical language - body, organism, blood circulation, will to life, Volkskörper, and so on - characteristic of the writings of geographer and ethnographer Friedrich Ratzel (1844-1904), who coined the term Lebensraum and was also among the first scholars to deploy the notion of geopolitics. Meisner further discussed the interpretation of Ratzel's concept of life forms in the geopolitical sense in the work of political scientist Johan Rudolf Kjellén (18641922). It is not by chance that the Nazis applied these buzzwords to justify an aggressive expansionist agenda and warfare as legitimate political means. However, Meisner's writings in these years seems to be closer to a conservative political discourse of intellectuals such as Carl Schmitt (1888-1985). That is to say that at this point, it was not yet clear that these arguments would give way to the rise of national socialism.

In the articles Meisner wrote while serving in the General Staff, he spoke of the fate of Prussia and Germany. His argumentation strove for balance and 
Sachlichkeit, discussing positions in a manner that measured each one against the other. Even though he avoided positioning himself, his texts nonetheless clarify where he stood. In his article "Nationale Besinnungen «, he contemplated the character of the "Great Powers« involved in World War I. He discussed German against French and British political theorists. Here, Meisner continued a Rankean tradition of historiography understood as struggle of Great Powers and a primacy of foreign policy over home affairs in a nationalist fashion. ${ }^{92}$ In times of war, he observed, the nation-state would change its characteristics. "The name of the state currently shines in new splendour. «"33 What reveals itself in the nation-state, he claimed, is the "contradiction of human nature ${ }^{94}$ in janiform. The experience of the belonging to the state, according to Meisner, was what defined human existence. The state, however, was caught up in a constant struggle of Great Powers. This is what defined its very nature.

The struggle of Great Powers was transformed into individual experience within a collective: The emphatic experience of the state (»das große sStaatserlebnis«) created a novel sense of community, alluding, without using the word, to what others called Volksgemeinschaft. ${ }^{95}$ »Thousands, who so far were overwhelmed by their day-to-day worries living as atomized individuals, now were at once taken by an unknown sense of community, a feeling of supraindividual potency. ${ }^{96}$ This potency, in Meisner's view, was not historically contingent and emergent but a matter of a quasi-natural vital energy (Lebenskraft). Using a quotation by Macchiavelli [sic], he paraphrased this passage - again, pretending to be objective, impartial, and sachlich - in order to insert his agenda into what, on first glance, only seems to refer to Machiavelli. His summary reads as follows: »This procreative instinct (Zeugungstrieb) of the individual peoples (Völkerindividuen) (if one may say so [Of course, one may not! It is entirely Meisner's invention.]) resembles the vital energy of the individual human being. $\star^{97}$ For good measure, consider the following: This was the prelude to the nationalist "Besinnung", a coming back to senses, which would play out as the "drive for expansion of a powerful Volkskörper«, something Meisner, without any desire for a critical stance, considered a "natural and known in which this life form translates into a bureaucratic mode of existence, a passage in which Meisner quotes the chemist, philosopher, and Nobel laureate Wilhelm Ostwald (1853-1932) - also author of a general theory of the energetic foundations of "Kulturwissenschaften «, organizer and standardizer on a global scale, ${ }^{99}$ as well as friend and avid reader of Ratzel -, at length: „We, or rather the German race have discovered the factor of organization. Other peoples live under the rule of individualism, we under that of organization. The level of organization is a higher level of civilization. [...] The war will teach them the form of this organization and allow them to partake in our higher civilization. «100

It may be slightly exaggerated to claim that Meisner's political stance on historical revisionism found expression in the revisions he made to his copy of "Aktenkunde«. Yet, his political attitude and his worldview certainly did inform his thinking about the world of archives, whose institutional logic in turn shaped his intellectual work. Meisner may have been a second-rate scholar. However, he did have a certain talent for translating intellectual discourse about Prussian politics into bureaucratic practice. In that sense, he falls into a category of what Peter Schöttler has called the "background figure ${ }^{101}$ The kind of intellectual bureaucracy we are dealing with here may be best characterized as the mediocracy of evil. ${ }^{102}$ Lots of intellectual energy and work were used to rethink the politics of the Prussian state in bureaucratic terms. This rethinking of the state in concrete bureaucratic terms yet again became the prerequisite for the ways in which life outside the archive could be acknowledged within the logic of state administration by files.

\section{Conclusion}

This look inside the bureaucratic institution and its intellectual and administrative practices, as well as the various kinds of paperwork that keeps them going, allows for a different perspective on the history of bureaucracy. Looking at the everydayness of intellectual and bureaucratic practice allows for a better understanding of the resources that facilitate it. Furthermore, this perspective also makes it clear that Kafka's cage will never catch the bird alive while 
the bird cannot escape the very idea of being caged. This does not change the fact that bureaucracy is a powerful, rational, and potentially violent form of governance and that its paperwork is set up to include and exclude in unequal terms, i.e., both with respect to the bureaucratic existence of individual subjects and their archival afterlives. The issue of who is recognized as citizen through paperwork is echoed by the problem that only those individuals from the past whose existence has left bureaucratic traces can be included in historical representations through archival materials. There is, of course, always an alternative existence, sans papier or in all kinds of counterarchives. Because the logics of everyday life cannot be translated to the emergent and changing rationality of bureaucracy, life outside of the archive can only be represented through the material traces it leaves within the papery organism of state administration. This necessary difference between the two logics, within and outside of bureaucratic paperwork, creates two territories that do not map onto each other but are positioned against each other in ethnographic perspective. Traveling and translating between them necessarily entails a symbolic economy of travel to navigate between the two forms' emergent rationality and the double contingency every instance of encounter between them implies. However, when the bureaucratic institution becomes heterotopic, i.e., whenever it makes us believe to have caught the bird, it becomes a place of the other. In that moment, its discourse turns structurally heterologic and thus its analysis has to turn to a theory of the other, be it ethnographic, psychoanalytic, or radically historical.

Along these lines, this essay aimed at providing a historically informed anthropological perspective from within. Looking at the everyday practice of bureaucracy in ethnographic perspective may turn out to be one possible way of provincializing Europe from within. This approach may offer one way of understanding the conditions and possibilities that shaped what we take to be the nature of bureaucracy, a nature that is contingent on the historically changing perspectives its critics and defenders use. In that sense, Meisner's attempts at defining its nature and describing its underlying logic are nothing but historically contingent endeavors to catch Kafka's bird although the latter will ultimately forever fly free. 
1 The research for this article was supported by the Swiss National Science Foundation. I want to thank the three anonymous reviewers and the editor Stefan Nellen for their valuable suggestions. Lisa Cronjäger, Larissa Dätwyler, Lucas Knierzinger, Aurea Klarskov and Henning Trüper have commented on an earlier version of this paper, and Aleksandr Rossman has helped with clarifying the flow of the argument. Over the years, Paul Rabinow has spent many afternoons in Berkeley's Cafe Mediterranean discussing how his way of doing anthropology and my way of doing history speak to each other.

2 Franz Kafka: The Zürau Aphorisms, London 2014 [1931], p. 16.

3 Dipesh Chakrabarty: Provincializing Europe, Princeton 2000.

4 A few paradigmatic examples are as follows: Bruno Latour / Steve Woolgar: Laboratory Life. The Construction of Scientific Facts, Princeton 1986; Karin Knorr-Cetina: The Manufacture of Knowledge. An Essay on the Constructivist and Contextual Nature of Science, Oxford 1981; Bruno Latour: The Making of Law. An Ethnography of the Conseil d'Etat, Cambridge 2010; Hélène Mialet: Hawking Incorporated. Stephen Hawking and the Anthropology of the Knowing Subject, Chicago 2012.

5 Gaston Bachelard: The Formation of the Scientific Mind: A Contribution to a Psychoanalysis of Objective Knowledge, 1986 [French original 1938].

6 Bruno Latour: Nous n'avons jamais été modernes: Essai d'anthropologie symétrique, Paris 1991.

7 Michel de Certeau: Heterologies. Discourse on the Other, Minneapolis 1986.

8 Bruno Latour: An Inquiry into Modes of Existence: An Anthropology of the Moderns, Cambridge 2013.

9 Paul Rabinow: Essays on the Anthropology of Reason, Princeton 1996, in particular, pp. 17-19.

10 The translation of the German Aktenkunde is delicate. According to international archival terminology, composed by the Project Group on Terminology of the International Council on Archives, "Aktenkunde« or, in English, »modern diplomatics ", is the »discipline that studies the genesis, forms, and transmission of archival documents and their relationship with the facts represented in them and with their creator, in order to identify, evaluate, and communicate their nature (URL: https://internet.archivschule.unimarburg.de/datiii/engterm.html\#diplomatics).

11 The problem is discussed in more detail in Heinrich Otto Meisner: Das Begriffspaar Urkunden und Akten, in: Staatliche Archivverwaltung im Staatssekretariat für innere Angelegenheiten (ed.): Forschungen aus mitteldeutschen Archiven. Zum 60. Geburtstag von Hellmut Kretzschmar, Berlin 1953, pp. 34-47.

12 Cornelia Vismann: Akten. Medientechnik und Recht, Frankfurt am Main 2000; see also the essay of Felix Lüttge in this volume.

13 This has to do with the success of the principle of provenance in the organization of archival materials. See Wolfgang Ernst / Cornelia Vismann: Die Streusandbüchse des Reiches. Preußen in den Archiven, in: Tumult. Schriften für Verkehrswissenschaft 21 (1995), pp. 87-107.

14 Helmut Lotzke: Heinrich Otto Meisner [Nachruf], in: ArchivMitteilungen 27 (1977), p. 37; Wolfgang Leesch: Heinrich Otto Meisner [Nachruf], in: Der Archivar 30 (1977), pp. 469-474; Leesch: Heinrich Otto Meisner, in: Neue Deutsche Biographie XVI, Berlin 1990, p. 689; Botho Brachmann: Zum 100. Geburtstag von Heinrich Otto Meisner«, in: Archiv-Mitteilungen 40 (1990), p. 41; Ute Essegern: Heinrich Otto Meisner. Sein Leben Werk und Nachlass, manuscript, Berlin 1994.

15 He argued that „das papierene Dokument einer Verfassung eine erschöpfende Regelung der zahlreichen staatlichen
Willensverhältnisse nie zu geben vermöge, stets würden die realen Machtverhältnisse zwischen Persönlichkeiten und Verbänden seine Paragraphen mit einem bestimmten Geiste erfüllen; sie solle das politische Leben in eine bestimmte Richtung weisen, nicht aber in starren Formen festlegen." Heinrich Otto Meisner: Die Lehre vom monarchischen Prinzip im Zeitalter der Restauration und des Deutschen Bundes, Breslau 1913, p. 13.

16 The state archive in Stettin was located in the rather young province of Pomerania (founded in 1815 and dissolved with the end of the Prussian state in 1945). Its first archivist had been Friedrich Ludwig von Medem, one of the founding figures of modern archival science and editor of the first journal in the field. At the time, when Meisner entered the archives, its holdings were rather limited and manageable, mostly holding modern materials. See Joachim Wächter: Die Entwicklung der pommerschen Provinzialarchivs in Stettin im Zusammenhang mit der Gesellschaft für pommersche Geschichte und Altertumskunde, in: Gesellschaft für pommersche Geschichte und Altertumskunde (ed.): Baltische Studien. Neue Folge Bd. 86, Marburg 2000.

17 See, for instance, Wolfgang Bialas / Georg G. Iggers (eds.): Intellektuelle in der Weimarer Republik, Oxford 1997; Ulrich Herbert: Geschichte Deutschlands im 20. Jahrhundert, München 2014.

18 Heinrich Otto Meisner: Deutscher und westeuropäischer Staatsbegriff, in: Deutsche Rundschau 43 (1916), pp. 65-76, 244255; Heinrich Otto Meisner: Über den Zusammenhang von innerund äußerer Politik, in: Die Grenzboten. Zeitschrift für Politik, Literatur und Kunst, 76/4 (1917), pp. 49-57; Heinrich Otto Meisner: Der Staat als Lebensform, in: Die Grenzboten. Zeitschrift für Politik, Literatur und Kunst, 76 (1917), 4, pp. 250-255; Heinrich Otto Meisner: Nationale Besinnungen, in: Die Grenzboten. Zeitschrift für Politik, Literatur und Kunst, 77/1 (1918), pp. 216-223; Heinrich Otto Meisner: Parlamentarismus, in: Die Grenzboten. Zeitschrift für Politik, Literatur und Kunst, 77/2 (1918), pp. 361-374; Heinrich Otto Meisner: Comme chez nous, in: Die Grenzboten. Zeitschrift für Politik, Literatur und Kunst, 77/2 (1918), pp. 314-318.

19 Heinrich Otto Meisner: Über das Archivwesen der russischen Sowjet-Republik. Beobachtungen während eines Studienaufenthalts in Moskau und Leningrad, in: Archivalische Zeitschrift 38 (1929), pp. 178-198. At this point, the relationship between German and Soviet archives was friendly. This would change as soon as Albert Brackmann took over the directorate of Prussian archival administration and called German archivists to join the battle against Russia and Poland.

20 Walter Vogel: Der Kampf um das geistige Erbe. Zur Geschichte der Reichsarchividee und des Reichsarchivs als "geistiger Tempel deutscher Einheit«, Bonn 1994; Matthias Herrmann: Das Reichsarchiv 1919-1945, 2 vols., dissertation, Berlin 1994; and most recently, Tobias Winter: Die Deutsche Archivwissenschaft und das "Dritte Reich«. Disziplingeschichtliche Betrachtungen von den 1920ern bis in die 1950er Jahre, Berlin 2018.

21 Wolfgang Ernst: Archival Action: The Archive as ROM and Its Political Instrumentalization under National Socialism, in: History of the Human Sciences 12/2 (1999), pp. 13-34 (https://doi. org/10.1177/09526959922120225).

22 Karl Heinz Roth: Eine höhere Form des Plünderns. Der Abschlußbericht der ,Gruppe Archivwesen der deutschen Militärverwaltung in Frankreich 1940-1944, in: 1999. Zeitschrift für Sozialgeschichte des 20. und 21. Jahrhunderts 4/2 (1989), pp. 79-112; Karl Heinz Roth: Klios rabiate Hilfstruppen. Archivare und Archivpolitik im deutschen Faschismus, in: Archivmitteilungen 
41/1 (1991), pp. 1-10; Ulrich Pfeil: Archivraub und historische Deutungsmacht. Ein anderer Einblick in die deutsche Besatzungspolitik in Frankreich, in: Francia 33/3 (2006), pp. 163194 (DOI: https://doi.org/10.11588/fr.2006.3.45400); Anja Heuß: Die Gruppe ‘Archivwesen im Spannungsfeld von Archivschutz und Archivraub, in: Ulrich Pfeil (ed.): Deutsch-französische Kultur- und Wissenschaftsbeziehungen im 20. Jahrhundert. Ein institutionengeschichtlicher Ansatz, München 2007, pp. 155-166; Matthias Berg: ১Die 760 Kisten gehen übermorgen nach Frankfurt.` Von der paradigmatischen zur physischen Aneignung von Archivalien durch die nationalsozialistische Judenforschung،, in: Matthias Berg / Jens Thiel / Peter Th. Walther (eds.): Mit Feder und Schwert: Militär und Wissenschaft-Wissenschaftler und Krieg, Stuttgart 2009, pp. 241-257. See more recently Peter Schöttler: Ressourcen in der NS-Geschichtswissenschaft - am Beispiel von „Westforschung und 'Archivschutzı, in: Sören Flachowsky / Rüdiger Hachtmann / Florian Schmaltz (eds.): Ressourcenmobilisierung: Wissenschaftspolitik und Forschungspraxis im NS-Herrschaftssystem, Göttingen 2016, pp. 178-196.

23 Bundesarchiv Berlin, Berlin Document Center, Ortsgruppendatei NSDAP, Meisner Heinrich, membership number 5'280.845. According to Meisner's record, his request to join the party was accepted on 1 May, 1937. This date allows to reconstruct that Meisner did not request membership before 1933. After the Nazi seize of power, the party, with few exceptions, did not accept new members until 1937. Many public officials joined the party rather late at the point when the majority of civil servants were forced to file for membership based on a new legislation. I want to thank Sebastian Markt for assistance with archival research on this point.

24 Archives of the Berlin-Brandenburg Academy of Science (A-BBAW): Nachlass Heinrich Otto Meisner, box 159, Newspaper clipping "Aus Groß-Berlin. Zeit ist Geld« (no pagination). In the following section, all quotations of Meisner refer to this newspaper article.

25 Anke Gleber: The Art of Taking a Walk. Flanerie, Literature, and Film in Weimar Culture, Princeton 1999; Andreas Mayer: Wissenschaft vom Gehen. Die Erforschung der Bewegung im 19. Jahrhundert, Frankfurt am Main 2013.

26 Max Weber: Economy and Society, 2 vols., Berkeley 1978 [1922], vol.1, p. 253; emphasis added.

27 »Dienstanweisung für die Beamten der Staatsarchive vom 24 January 1904«, in: Bestimmungen aus dem Geschäftsbereich der k. preussischen Archivverwaltung (Mitteilungen der k. preussischen Archivverwaltung, vol. 10), Leipzig 1908, p. 4.

28 Weber: Economy and Society.

29 Richard Swedberg: Max Weber and the Idea of Economic Sociology, Princeton 1998, p. 63.

30 Weber: Economy and Society, p. 957.

31 I fleshed out this argument in "Gehirnausstülpungen. Zur Wissenschaftsgeschichte intellektueller Arbeit«, in: Berichte zur Wissenschaftsgeschichte 41/4 (2018), pp. 449-452 (https://doi. org/10.1002/bewi.201801915).

32 Moreover, the archival search algorithms required a particular form of historical knowledge since the materials were organized along the administrative processes of their historical formation, i.e., the principle of provenance, a fundamental of archival classification that archivists just had agreed on at their first international meeting on the occasion of the Brussel Exposition Universelle et Internationale in 1910. From the vast literature on this matter, I only quote: Ernst Posner: Some Aspects of Archival Development since the French Revolution, in: The American Archivist 3/3 (1940) pp. 159-172; Nancy Bartlett: The Origins of the Modern Archival
Principle of Provenance, in: Bibliographical Foundations of French Historical Studies 1992, pp. 106-114; Shelley Sweeney: The Ambiguous Origins of the Archival Principle of `Provenance`, in: Libraries \& the Cultural Record 43/2 (2008), pp. 193-213. For the history of the world's fairs, Alexander C. T. Geppert: Fleeting Cities. Imperial Expositions in Fin-de-Siècle Europe, Basingstoke 2010.

33 Cornelia Vismann: Files. Law and Media Technology, Stanford 2008 [2000], p. xii. While Vismann looks at the history of files from the perspective of a philosopher of law and historian of media, Meisner's approach is that of an historian-archivist.

34 Johann Gustav Droysen: Historik, Band 1, Rekonstruktion der ersten vollständigen Fassung der Vorlesungen (1857); Grundriß der Historik in der ersten handschriftlichen (1857/1858) und in der letzten gedruckten Fassung (1882), hg. von Peter Leyh, Bad Cannstatt, 1977.

35 Johann Gustav Droysen: Geschichte der preussischen Politik, Leipzig 1855, vol. 1, p. v.

36 Johann Gustav Droysen: Geschichte, p. vii.

37 Anonymous, [Literaturbericht], in: Jahresberichte für Deutsche Geschichte 1930, p. 200.

38 Heinrich Otto Meisner: Preußen und der `Revisionismus, Eine Abwehr, in: Forschungen zur Brandenburgischen und Preußischen Geschichte 43 (1930), pp. 252-289, at p. 253.

39 Heinrich Otto Meisner: Aktenkunde, p. 1: "Das Paradigma ist Brandenburg-Preußen. Seine Kanzleipraxis eignet sich besonders für Demonstrationszwecke, weil die straffe Disziplin des Beamtentums sich auch im Kanzleiwesen nicht verleugnet und hier eine bemerkenswerte Einheitlichkeit [...] erzielt hat."

40 Heinrich Otto Meisner: Aktenkunde, p. 1: "Das Paradigma ist Brandenburg-Preußen. Seine Kanzleipraxis eignet sich besonders für Demonstrationszwecke, weil die straffe Disziplin des Beamtentums sich auch im Kanzleiwesen nicht verleugnet und hier eine bemerkenswerte Einheitlichkeit [...] erzielt hat."

41 Albert Brackmann: Das Institut für Archivwissenschaft und archivwissenschaftliche Fortbildung am Geheimen Staatsarchiv in Berlin-Dahlem, in: Archivalische Zeitschrift 40 (1931), pp. 1-16; Albert Brackmann: Das Dahlemer Institut für Archivwissenschaft und geschichtswissenschaftliche Fortbildung in den Jahren 1930-1932 und das Problem des archivarischen Nachwuchses, in: Korrespondenzblatt des Gesamtvereins der Deutschen Geschichtsund Alterthumsvereine 80 (1932), pp. 150-154; for the history of the institute, see Tobias Winter: Die deutsche Archivwissenschaft und das Dritte Reich. Disziplingeschichtliche Betrachtungen von den 1920ern bis in die 1950er Jahre, Berlin 2018, pp. 117-130.

42 After his training in Stettin in 1913-1914, Meisner returned to Berlin and took on a position at the Prussian Privy State Archives. Eckart Henning: Wie die Aktenkunde entstand. Zur Disziplingenese einer Historischen Hilfswissenschaft und ihrer weiteren Entwicklung im 20. Jahrhundert, (1999), in: Eckhart Henning (ed.): Auxilia Historica. Beiträge zu den historischen Hilfswissenschaften und ihren Wechselbeziehungen, Cologne 2004, pp. 105-127.

43 Annekatrin Schaller: Michael Tangl (1861-1921) und seine Schule. Forschung und Lehre in den Historischen Hilfswissenschaften, Stuttgart 2002.

44 Before Tangl joined the faculty of the Friedrich-Wilhelms-University, he had accepted a call to the new institute for historical auxiliary sciences at Marburg University in 1895.The institute was involved in the training of Prussian archivists and would, in 1950, take the institutional form of the West German Archivschule Marburg, which trains archivists to this day. See Andrea Rzihacek / Christoph Egger: Michael Tangl (1861-1921). Ein Österreicher in Berlin, in: 
Österreichische Historiker. Lebensläufe und Karrieren 1900-1945, vol 2, Karel Hruza (ed.), Vienna 2012, pp. 23-84.

45 Manfred Stoy: Das Österreichische Institut für Geschichtsforschung 1929-1945, München 2007; Ernst Zehetbauer: Geschichtsforschung und Archivwissenschaft. Das Institut für Österreichische Geschichtsforschung und die wissenschaftliche Ausbildung der Archivare in Österreich, Hamburg 2014; Daniela Saxer: Die Schärfung des Quellenblicks. Forschungspraktiken in der Geschichtswissenschaft 1840-1914, München 2014.

46 For Meisner's notes, see: Archives of BBAW, Nachlass Meisner, box 11.

47 Archives of BBAW: Nachlass Meisner, box 11, Notebook "Tangl. Lateinische Paläographie, Wintersemester 1909/1910«.

48 Archives of BBAW: Nachlass Meisner, box 11, Notebook »Tangl. Lateinische Paläographie, Wintersemester 1909/1910«, pp. 1-2, 17.

49 All previous quotations are from Meisner: Aktenkunde, p. 3.

50 Most recently, Michael Hochedlinger: Aktenkunde. Urkundenund Aktenlehre der Neuzeit, Vienna 2009. See also Gerhard Schmid: Akten, in: Friedrich Beck / Eckhart Henning (eds.): Die archivalischen Quellen. Mit einer Einführung in die Historischen Hilfswissenschaften, Cologne 2004 [1994]; Jürgen Kloosterhuis: Amtliche Aktenkunde der Neuzeit. Ein hilfswissenschaftliches Kompendium, in: Archiv für Diplomatik 45 (1999), pp. 465-563.

51 See Mary Douglas: How Institutions Think, Syracuse, NY 1986.

52 The main changes of the office reform with respect to the creation and processing of files were the abolishment of the journal, the dissolution of centralized registries (Zentralregistraturen), the introduction of the so-called Aktenplänen (file plan) - which anticipated the structuring of the tradition of files along with the introduction of the Aktenzeichen, an identifier for each individual document containing a number code to identify the place within the topography of the file plan and an unique serial number. Arnold Brecht: Die Geschäftsordnung der Reichsministerien. Ihre staatsrechtliche und geschäftstechnische Bedeutung. Zugleich ein Lehrbuch der Büroreform, Berlin 1927. See Meisner's discussion of the problem: Heinrich Otto Meisner: Fragen der Büroreform, in: Mitteilungsblatt der preußischen Archivverwaltung 1941, pp. 14-25.

53 Universalist systems of classification, of course, do have a long history of their own. See, for instance, Geoffrey C. Bowker / Susan Leigh Star: Sorting Things Out: Classification and Its Consequences, Cambridge 2000.

54 See Sheldon Pollock / Benjamin A. Elman / Ku-ming Kevin Chang (eds.): World Philology, Cambridge 2015.

55 Roger Chartier: Inscrire et effacer: culture écrite et littérature (XIeXVIIIe siècle), Paris 2005; Anthony Grafton: Worlds Made By Words. Scholarship and Community in the Modern West, Cambridge 2009, in particular, pp. 56-78; Ben Sherman: Used Books. Marking Readers in Renaissance England, Philadelphia 2008; Ann Blair: Too Much to Know: Managing Scholarly Information before the Modern Age, New Haven, London 2010.

56 Particular striking examples of both this intellectual practice and the analyses thereof are Henning Trüper: Das Klein-Klein der Arbeit. Die Notizführung des Historikers François Louis Ganshof, in: Österreichische Zeitschrift für Geschichtswissenschaften 18/2 (2007), pp. 82-104; Trüper: Unordnungssysteme. Zur Praxis der Notizführung bei Johan Huizinga, in: Zeitenblicke 10/1 (2011), [urn:nbn:de:0009-9-30517]; Henning Trüper: Topography of a Method: François Louis Ganshof and the Writing of History, Tübingen 2014; Christoph Hoffmann: Schreiben im Forschen, Tübingen 2018, especially chap. 2.

57 Markus Krajewski: Paper Machines. About Cards \& Catalogs, pp. 1548-1929, Cambridge 2011.
58 Krajewski: Paper Machines, p. 3.

59 Friedrich Kuntze: Die Technik der geistigen Arbeit, Heidelberg 1921. I also choose this example because it is not discussed in Krajweski's book.

60 Kuntze: Technik, p. V: »Ich sah dort in einem überwältigenden Beisammen die sinnvollen Hilfsmittel und oft genialen Organisationsmethoden, die der moderne Kaufmann sich geschaffen hat, hielt dagegen meine eigenen - die traditionellen - unpraktischen Arbeitsmethoden, überschlug zu der Ersparnis an Arbeitskraft die Steigerung der Leistungen, die sich beide durch eine Vervollkommnung dieser Methoden gewinnen ließen.«

61 Kuntze, Technik, p. 2: "[...] Aufnehmen[s], Anordnen[s], Produzieren[s] «.

62 Kuntze, Technik, p. 7.

63 The intellectual practice of cut and paste was certainly not unique to Meisner's work. See Anke te Heesen: The Newspaper Clipping. A Modern Paper Object, Manchester 2014.

64 He stopped using his copy of the "Aktenkunde« as a notebook in 1950. To the best of my knowledge, no comparable copy of the "Urkunden- und Aktenlehre» exists in his Nachlass or anywhere else. It, therefore, seems plausible that Meisner had decided at some point to revise his first publication on the matter. However, this was not clear from the very beginning of the project to collect notes and materials in his own copy of the »Aktenkunde«.

65 Göttinger Gelehrte Anzeigen, 208, 3/4 (1954), pp. 221-232.

66 Meisner notes: „B.s Lehre vom >Archivkörper im idealen Sinne, die den gewachsenen Zusammenhang der Registraturnicht >denaturiert (wie der französische Fonds nach einheimischem Urteil), aber auch nicht, wenn durch Verschulden des Registrators krankhaft gewachsen, um des Registratur- oder ,Erwachsungsprinzips، willen starr konserviert, sondern elastische behandelt und dabei schöpferisch zur wirklichen 'Sachgemeinschaftı gestaltet, bezweckt die Synthese von Herkunft und Sache, d.h. die Überwindung des säkularen Spannungsverhältnisses von Provenienz und Pertinenz auf einer höheren Ebene."

67 Archive BBAW, Nachlass Meisner: Aktenkunde, p. 11 note, left page.

68 Meisner: Aktenkunde, p. 2.

69 Meisner: Aktenkunde, p. 2

70 Meisner: Aktenkunde, p. 2.

71 See my »Die kalte Sprache des Lebendigen. Zu den Anfängen der Archivberufssprache«, in: Peter Becker (ed.): Sprachvollzug im Amt Kommunikation und Verwaltung im Europa des 19. und 20. Jahrhunderts, transcript, Bielefeld 2011, pp. 45-75.

72 Rodolf Thommen: Urkundenlehre, 1. und 2. Teil. Grundbegriffe, Königs- und Kaiserurkunden, 2nd edition, Leipzig 1913.

73 "alle formelhaften Elemente so weit abgestoßen haben, daß man 35 sie fast zu den Akten rechnen möchte."

74 »... auf ein Rechtsgeschäft hinführen, nichts Absolutes, nur Relatives ... Bittner, H.Z. 1935, S. 532"

75 Alfred Döblin: Berlin Alexanderplatz. Translated with an Afterword by Michael Hofmann, London 2019 [German 1929], p. 38.

76 Talcott Parsons et al.: Some Fundamental Categories of the Theory of Action. A General Statement, in: Talcott Parsons / Edward A. Shils (eds.): Toward a General Theory of Action, Cambridge 1951, pp. 3-29, at p. 16.

77 Claudio Baraldi: Doppelte Kontingenz, in: Claudio Baraldi / Giancarlo Corsi / Elena Esposito: GLU. Glossar zu Niklas Luhmanns Theorie sozialer Systeme, Frankfurt am Main 1997, p. 37.

78 Arnold Esch: Überlieferungs-Chance und Überlieferungs-Zufall als methodisches Problem des Historikers, in: Historische Zeitschrift 240 (1985), pp. 529-570. 
79 Natalie Davis: Historische Einbildungskraft, in: Anne Kwaschik / Mario Wimmer (eds.): Von der Arbeit des Historikers. Ein Wörterbuch zu Theorie und Praxis der Geschichtswissenschaft, Bielefeld 2010, pp. 107-109.

80 I adopt this model from Michel de Certeau: The Writing of History, New York 1992.

81 Michel Foucault: Of Other Spaces, in: Diacritics 16/1 (1986), pp. 2227.

82 Foucault: Of Other Spaces, p. 23.

83 Foucault: Of Other Spaces, p. 23.

84 Paul Rabinow: Studies in the Anthropology of Reason, in: Anthropology Today 8/5 (1992), pp. 7-10.

85 A notion that, by the way, also Max Weber shared in a letter to a colleague worried about his bad memory that required to be supplemented by notes and scribbles: Letter of Max Weber to Heinrich Herkner, Heidelberg, 29 March, 1909, GSta Berlin, Rep. 92, NI Max Weber, Nr. 18, Bl. 9-10 (edited in Max Weber Gesamtausgabe, Briefe, vol. 6, Briefe 1909-1910, M. Rainer Lepsius and Wolfgang J. Mommsen with Birgit Rudhard and Manfred Schön (eds.), Tübingen 1994, pp. 86-87.) While, today, in legal discourse, the principle of oral presentation (of cases in court) is the norm, Prussian legal procedures were based on files, the so-called Aktenprozess followed the principle of literality or writtenness, i.e., only what existed in writing could be considered during deliberations and to reach a verdict.

86 Heinrich Otto Meisner: Staatsanschauung, in: Jahresberichte für deutsche Geschichte, 5 (1922), pp. 117-128, at p. 117

87 Meisner: Revisionismus, p. 274

88 Hermann Sudermann: Heimat, Berlin 1893. Being his most successful play, »Heimat" premiered in 1893 but was put on stage numerous times over the following decades. It was also popular in England and the United States, where the Magda was performed by famous actresses such as Sarah Bernhardt or Eleonora Duse.

89 Other cosigners included Max Planck or Rudolf Eucken, that is to say, Sudermann was in good company and the enthusiasm for a war during its early phase was wide ranging and great.

90 Meisner: Revisionismus, p. 283.

91 Meisner: Revisionismus, p. 272.

92 For Meisner's reading of Ranke, see his Introduction in: Leopold Ranke: Illustrierte Weltgeschichte: Auf Grundlage der Geschichtswerke von Leopold von Ranke hg. v. Paul Hartung bearb. u. erg. von Bernhard Schneider mit einer Einführung v. Heinrich Otto Meisner, Berlin 1931.

93 Meisner: Der Staat als Lebensform, p. 250.

94 Meisner: Der Staat als Lebensform, p. 250.

95 The word was first used in the late 18th century and became a buzz word during World War I, even though not in a racial but in a nationalist sense. Scholarship on this term is vast; therefore, I mention just two excellent studies in the history of the notion and the politics it involved: Michael Wildt: Hitler's Volksgemeinschaft and the Dynamics of Racial Exclusion: Violence Against Jews in Provincial Germany, 1919-1939, New York 2014; and the classical study by Detlev Peukert: Inside Nazi Germany: Conformity, Opposition, and Racism in Everyday Life, Yale 1989.

96 Meisner: Der Staat als Lebensform, p. 250.

97 Meisner: Nationale Besinnungen, p. 216.

98 Meisner: Nationale Besinnungen, p. 216.

99 Markus Krajewski: World Projects: Global Information before World War I, Minneapolis 2014.

100 Meisner: Nationale Besinnungen, p. 218, is quoting from an interview with the Swedish newspaper Dagen.
101 Peter Schöttler: Three Kinds of Collaboration: Concepts of Europe and the 'Franco-German Understanding, - The Career of SSBrigadeführer Gustav Krukenberg, in: Dieter Gosewinkel (ed.): AntiLiberal Europe. A Neglected Story of Europeanization, New York 2015, pp. 128-156.

102 This is an allusion to Hanna Arendt: Eichmann in Jerusalem. A Report on the Banality of Evil, New York 1963; Hannah Arendt / Joachim Fest: Eichmann war von empörender Dummheit. Gespräche und Briefe, Ursula Ludz / Thomas Wild (eds.), Piper, München 2011. 


\section{Abstract}

In this essay I lay out an argument about the scholarship on the emergent rationality of files. Looking at the case of Heinrich Otto Meisner's groundbreaking modern diplomatics of files and the conditions and possibilities that shaped the argument of his work both practically and politically, I suggest a model for the analysis of bureaucratic mediocracy in historical perspective. I argue for an historical anthropology that acknowledges the epistemic violence and politics of inclusion and exclusion in bureaucracy in order to arrive at an historical anthropology of reason that does not deny, but instead attempts to think through its unequal terms.

\section{About the Author}

Mario Wimmer is a historian of science and media. He teaches history and theory of media at Basel University and currently helps run the interdisciplinary research group >Media of Exactituder. His research focuses on the history of the modern human sciences, the social history of media technologies, the institutional history of knowledge, and the history of intellectual work. At the moment, he is working on a book manuscript titled Ranke's Blindness. His publications include: Archivkörper. Eine Geschichte historischer Einbildungskraft (Konstanz University Press 2012; re-edition 2013); »On Sources. Historical and Mythical Thinking in Fin de Siècle Vienna«, in: Res. Journal for Anthropology and Aesthetics 63/64 (2013), 108-124; "The Present as Future Past: Anonymous History of Historical Times«, in: Storia della storiografia (2015), 165-184. 